\title{
Effect of Shading on Photovoltaic Cell
}

\author{
${ }^{1}$ Ekpenyong, E.E and ${ }^{2}$ Anyasi, F.I \\ ${ }^{1}$ Department of Electrical/Electronic Engineering, Cross River University of Technology, P.M.B 1123, \\ Calabar. Nigeria. \\ ${ }^{2}$ Department of Electrical and Electronics Engineering, Ambrose Alli University, P.M.B 14, Ekpoma, Edo State,
} Nigeria.

\begin{abstract}
Photovoltaic (PV) power systems have been widely applied in commercial and domestic facilities. Electrical Energy Storage (EES) systems are mandatory in standalone PV systems for continuous power supply. In this paper the efficiency and robustness enhancement methods for PV systems under partial shading have been investigated. Partial shading due to moving clouds and shadows of nearby obstacles on the PV module array causes significant efficiency degradation, since shaded and non-shaded PV modules have large discrepancy in their maximum power points. Use of by-pass diodes for each PV module may mitigate the negative effect from partial shading. However, this method alone may still face severe energy efficiency degradation caused by the energy loss due to parasitic effects in the EES elements under variable incoming power from the PV modules. Hence, this paper investigates the effect of shading on photovoltaic cells.
\end{abstract}

\section{Introduction}

Solar energy refers primarily to the use of solar radiation for practical electricity generation. However, there are other renewable energies like natural gas, coal and bio fuel. Solar radiation along with other secondary solar powered resources such as wind, geothermal, tidal and wave power, hydroelectricity and biomass, account for most of the available renewable energy on the earth. Only minuscule fraction of the available solar energy is used [1].

Over the years, solar energy has been gaining ground as a source of electricity. Photovoltaic cells convert sunlight directly to electricity. Photovoltaic (PV) cells utilize semi - conductor technology to convert solar radiation directly into an electric current which can be used or stored. Photovoltaic is a combination of two words "Photo" from Greek root meaning, light and "Voltaic" from volt which is the unit used to measure Electric potentials at a given point [2].The Photovoltaic effect was first noted by a French Physics that certain material would produce small amount of Electric field, ALBERT EINSTEIN described the nature of light and photovoltaic technology that it was too expensive to gain wider spread use in 1954 [3].Sunlight is made up of tiny particles called photons which are being converted to electrical energy. Every hour, enough of this energy reaches the world to meet the world's energy demand for the whole world. Photovoltaic panels consists of many solar cells, these are made of materials like silicon, one of the most common elements on earth. The individual cell is designed with a positive and a negative layer to create an electric field, just like in a battery. As photons are absorbed in the cell, their energy causes electrons to become free, the electrons move toward the bottom of the cell, and exit through the connecting wire. The flow of photons is what we call electricity. By combining solar cells and photovoltaic panels, we can produce just the right amount of electricity to perform a specific job, no matter how large or small, Solar energy is the energy derived from the sun through a form of solar radiation [3]. Solar powered electricity generation relies on photovoltaic cells and heat engines. A partial list of other solar applications include space heating and cooling through solar architecture, day lighting, solar hot water, solar cooking, and high temperature process heat for industrial purposes. Solar technologies are broadly characterized as either passive solar or active solar depending on the way they capture, convert and distribute solar energy. Active solar techniques include the use of photovoltaic panels and solar thermal collectors to harness the energy. Passive solar techniques include orienting a building to the Sun, selecting materials with favourable thermal mass or light dispersing properties, and designing spaces that naturally circulate air. Photovoltaic (PV) cells convert sunlight directly to electricity. They work any time the sun is shining, but more electricity is produced when the sunlight is very strong and strikes the PV cells directly. The basic building block of PV technology is the solar cell. The PV cell consists of two or more layers of semi-conducting material, most commonly silicon. When the silicon is exposed to light, electrical charges are produced and can be conducted away by metal contacts as Direct Current (DC). The current from a single cell is small, so, multiple PV cells are connected together and sealed behind glass to form a module known as SOLAR PANEL [3]. PV allows you to produce electricity, without noise, air pollution and fuel. Most PVs have a life span of $25-50$ years. Solar power in rural areas is a viable alternative for providing electricity for telecommunications, telemetry, water pumping, lighting, television, DC refrigeration and other low power non- heating applications. Heating appliances such as kettles, toasters, stoves, geysers and heaters are consuming too much energy and 
therefore cannot be used on a solar system [2].The basic components for this solar energy system are; solar panel, charge controller, battery, inverter, wiring, and connected loads.

\section{Methodology}

Given that the total estimated load in kilowatts $(\mathrm{KW})$ is $915 \mathrm{KW}$. To effectively and efficiently select other components, for example the inverter, we must convert the power in kilowatts to the kilovolt-ampere (KVA). The conversion factor below is applied.

$\mathrm{KVA}=\mathrm{KW} / 0.8$

Therefore; $915 \mathrm{~W} / 08=1143.75 \mathrm{VA}$, which is approximately $1.5 \mathrm{KVA}$

Based on the estimated loads, the sizes and capacity of the system components were determined, and are shown in the Table 1.

Table 1: System Components and Capacity

\begin{tabular}{|l|l|l|l|l|}
\hline S/N & EQUIPMENT & QUANTITY & $\begin{array}{l}\text { CAPACITY PER } \\
\text { EQUIPMENT }\end{array}$ & COMBINED CAPACITY \\
\hline 1. & SOLAR PANEL & $4(80 \mathrm{w} \times 4)$ & $320 \mathrm{WATT}$ & $320 \mathrm{WATTS}(24 \mathrm{~V})$ \\
\hline 2. & $\begin{array}{l}\text { CHARGE } \\
\text { CONTROLLER }\end{array}$ & 1 & $20 \mathrm{AMPS} / 24 \mathrm{~V}$ & $20 \mathrm{AMPS} / 24 \mathrm{~V}$ \\
\hline 3. & $\begin{array}{l}\text { DEEP CYCLE } \\
\text { BATTERY }\end{array}$ & 2 & $200 \mathrm{AH}, 12 \mathrm{~V}$ & $200 \mathrm{AH}, 24 \mathrm{~V}$ \\
\hline 4. & INVERTER & 1 & $1.5 \mathrm{KVA}(24 / 220 \mathrm{~V})$ & $1.5 \mathrm{KVA}(24 \mathrm{~V} / 220 \mathrm{~V})$ \\
\hline
\end{tabular}

This solar energy system is designed to supply constant power to the estimated loads for an average working period of about six (8) hours daily, for the entire functioning life of the system.

\section{Effect of Shading}

Shading can have a huge impact on the performance of solar photovoltaic panels. It is obvious that the best solution is to avoid shading altogether, though this isn't possible in practice due to factors like cloud, rain etc. but what many people don't realize is that even if a small section of the solar photovoltaic panel is in shade, the performance of the whole solar photovoltaic panel will significantly reduce. This is because solar photovoltaic panels actually consist of a number of solar photovoltaic cells that are wired together into a series circuit. This means that when the power output of a single cell is significantly reduced, the power output for the whole system in series is reduced to the level of current passing through the weakest cell. Therefore, a small amount of shading can significantly reduce the performance of your entire solar photovoltaic panels system [1]. One of the main causes of losses in energy generation within photovoltaic systems is the partial shading on photovoltaic (PV modules). These PV modules are composed of photovoltaic cells (PV cells) serial or parallel connected, with diodes included in different configurations. The curve of a PV cell varies depending on the radiation received [1][2] and its temperature. Furthermore, the modules have diodes that allow the current flows through an alternative path, when enough cells are shaded or damaged. There are two typical configurations of bypass diodes: [3] overlapped (Fig. 1a) and no-overlapped (Fig. 1b). It should be noted that the analysis in modules with overlapped diodes is a more complex one, because there may be different paths for current flow. This paper examines the individual behaviour of a PV module and a photovoltaic array of PV modules (PV array) connected to an inverter with shadows in both cases.

The impact of partial shading on PV system has been studied at great length in the past [4]-[5]. Some past studies assume that the decrease in power production is proportional to the shaded area and reduction in solar irradiance, thus introducing the concept of shading factor. While this concept is true for a single cell, the decrease in power at the module or array level is often far from linearity with the shaded portion [6].

Other past studies tend to be rather complicated and difficult to follow by someone with limited knowledge on electronic/solid-state physics [7].

The specific objective of this work is to clarify the impact of shading on a solar panel performance in relatively simple terms that can be followed by a power engineer or PV system designer without difficulty.

First, the circuit model of a PV cell and its I-V curve are reviewed. This is followed by the impact of partial shading on the I-V and P-V curves of a circuit containing two cells with and without bypass diodes and more. 


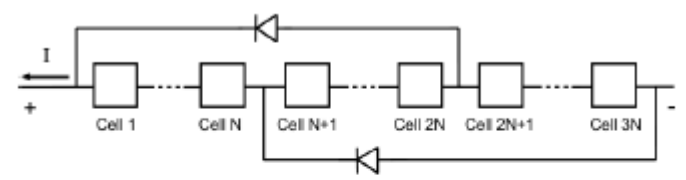

(a)

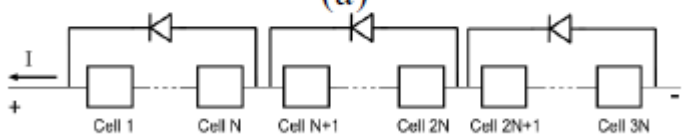

(b)

Source: Applied Energy 86 (2009)

Fig.1 Bypass diodes (a) overlapped (b) no-overlapped

\section{PV Cell Model}

A mathematical description of current - voltage terminal characteristics for PV cells is available in literature. The single exponential equation (1) which models a PV cell is derived from the physics of the PN junction and is generally accepted as reflecting the behaviour of the PV cell. A double exponential equation may be used for the polycrystalline Silicon cells [4].

$I=I_{p h}-I_{s}\left(\exp \frac{q \cdot\left(V+I R_{g}\right)}{N . K . T}\right)-\frac{\left(V+I R_{g}\right)}{R_{s h}}$

Working backwards from the equations, an equivalent circuit can be easily determined, and this aids to the development of the simulation model [1]. This equivalent circuit model is shown in Fig.2.

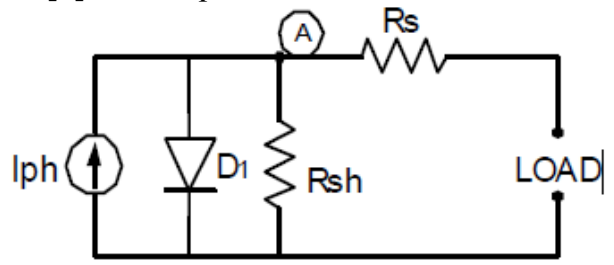

Fig.2: PV Cell circuit model

Source: IEE Proceeding Electric power Application

The complete behaviour of PV cells are described by five model parameters $\left(I_{p h}, N\right.$, Is, Rs, $\left.R_{s h}\right)$ which is representative of a physical PV cell/module [4]. These five parameters of PV cell/module are in fact related to two environmental parameters of solar insulation \& temperature and owing to non-linear nature of equation (1) their determination is not straightforward.

\section{TESTS AND RESULTS OF PV SYSTEM}

\section{Tests}

The following general tests were performed on all the parts of the system installation as required.

i. $\quad$ Voltage tests (all)

ii. Continuity tests (wiring and cable terminations)

iii. Frequency tests (Mains supply and inverter output)

iv. Short circuit and overload tests (inverter, load, wiring and cable terminations)

v. Polarity tests (all)

Solar Panel Test

The tests performed on the solar panels are summarized in the table below.

NOTE: All measured values was taken on the $13^{\text {th }}$ November, 2012 as shown in Table 2 and 3

Table.2: Solar Panel Tests

\begin{tabular}{|c|c|c|c|c|c|}
\hline S.N & Name of test & $\begin{array}{l}\text { Rated value (from } \\
\text { name plate) }\end{array}$ & $\begin{array}{l}\text { Measured value per } \\
\text { panel }\end{array}$ & $\begin{array}{l}\text { measured value for } \\
\text { four panels in } \\
\text { series/parallel }\end{array}$ & Remarks \\
\hline 1 & Open circuit voltage & $21.3 \mathrm{~V}$ & $18.7 \mathrm{~V}$ & $38.5 \mathrm{~V}$ & $\begin{array}{lr}\text { Varies } & \text { with } \\
\text { amount } & \text { of } \\
\text { sunlight } & \\
\end{array}$ \\
\hline 2 & Peak voltage & $17.1 \mathrm{~V}$ & $18.7 \mathrm{~V}$ & $38.5 \mathrm{~V}$ & “ \\
\hline 3 & Peak current & 4.67A & NIL & 7.35 & “ \\
\hline 4 & Short circuit current & $5.3 \mathrm{~A}$ & NIL & NIL & “ \\
\hline 5 & Max. system voltage & $600 \mathrm{~V}$ & NIL & NIL & “ \\
\hline 6 & Peak power & $80 \mathrm{~W}$ & $70.75 \mathrm{~W}$ & $282.98 \mathrm{~W}$ & “ \\
\hline
\end{tabular}


Charge regulator, battery and Inverter tests.

With all the appliances connected but with the load still disconnected the results for this test is summarized in the Table 3.

Table. 3: Charge regulator, battery and inverter tests

\begin{tabular}{|l|l|l|l|l|}
\hline S.N & Equipment & Input voltage & Output voltage & Output frequency \\
\hline 1 & Charge regulator & $24-38.5 \mathrm{~V} \mathrm{dc}$ & $28 \mathrm{~V} \mathrm{dc}$ & NIL \\
\hline 2 & Battery (2 batteries in series) & $28 \mathrm{~V} \mathrm{dc}$ & $28 \mathrm{~V} \mathrm{dc}$ & NIL \\
\hline 3 & Inverter & $28 \mathrm{~V} \mathrm{dc}$ & $224.5 \mathrm{~V} \mathrm{ac}$ & $50.04 \mathrm{HZ}$ \\
\hline
\end{tabular}

\section{PV characteristics.}

To know the characteristic of a PV, hourly readings was taken for 10hours, values for Voltage and Current using Voltmeter and Ammeter connected in parallel with the solar array was gotten. The values of Power were gotten from calculation using the formula:

$\mathbf{P}=\mathbf{I V}$

.2

Where, $\mathrm{P}$ is Power,

$\mathrm{I}$ is Current and

$\mathrm{V}$ is Voltage.

Shading Characteristics.

Table: 4: Measured Values for PV Characteristics with Shading Day1, $15^{\text {th }}$ Nov 2012

\begin{tabular}{|l|l|l|l|l|l|l|l|l|l|l|}
\hline Time (Hours) & 8 & 9 & 10 & 11 & 12 & 13 & 14 & 15 & 16 & 17 \\
\hline $\begin{array}{l}\text { Voltage } \\
\text { (Volts) }\end{array}$ & 35.9 & 37.5 & 37.7 & 37.8 & 37.9 & 37.8 & 37.6 & 37.5 & 37.6 & 37.2 \\
\hline Current (A) & 3.94 & 2.45 & 1.64 & 3.55 & 4.27 & 4.20 & 2.86 & 2.51 & 2.46 & 1.79 \\
\hline $\begin{array}{l}\text { Power } \\
\text { (Watts) }\end{array}$ & $\begin{array}{l}141.4 \\
5\end{array}$ & 91.88 & 61.83 & 134.19 & 161.83 & 158.76 & 107.54 & 94.13 & 92.50 & 73.28 \\
\hline
\end{tabular}

Table: 5: Measured Values for PV Characteristics with Shading Day 2, $16^{\text {th }}$ Nov, 2012

\begin{tabular}{|l|l|l|l|l|l|l|l|l|l|l|}
\hline $\begin{array}{l}\text { Time } \\
\text { (Hours) }\end{array}$ & 8 & 9 & 10 & 11 & 12 & 13 & 14 & 15 & 16 & 17 \\
\hline $\begin{array}{l}\text { Voltage } \\
\text { (Volts) }\end{array}$ & 30.9 & 38.5 & 38.2 & 38.4 & 38.8 & 37.6 & 38,8 & 25.5 & 25.0 & 24.8 \\
\hline Current (A) & 0.83 & 2.07 & 3.04 & 6.42 & 7.52 & 8.80 & 6.05 & 1.17 & 1.12 & 1.00 \\
\hline $\begin{array}{l}\text { Power } \\
\text { (Watts) }\end{array}$ & 25.65 & 79.70 & 116.13 & 246.53 & 291.80 & 330.90 & 234.74 & 29.84 & 28.60 & 24.8 \\
\hline
\end{tabular}

Table: 6: Average Values for PV Characteristics with Shading.17 ${ }^{\text {th }}$ November, 2012

\begin{tabular}{|l|l|l|l|l|l|l|l|l|l|l|}
\hline $\begin{array}{l}\text { Time } \\
\text { (Hours) }\end{array}$ & 8 & 9 & 10 & 11 & 12 & 13 & 14 & 15 & 16 & 17 \\
\hline $\begin{array}{l}\text { Voltage } \\
\text { (Volts) }\end{array}$ & 33.4 & 38.0 & 37.9 & 38.1 & 38.4 & 37.7 & 38.2 & 31.5 & 31.3 & 31.0 \\
\hline Current (A) & 2.40 & 2.30 & 2.34 & 4.90 & 5.80 & 6.50 & 4.50 & 1.84 & 1.79 & 1.50 \\
\hline $\begin{array}{l}\text { Power } \\
\text { (Watts) }\end{array}$ & 83.60 & 85.80 & 89.00 & 190.36 & 226.82 & 244.83 & 171.14 & 62.00 & 60.55 & 49.04 \\
\hline
\end{tabular}

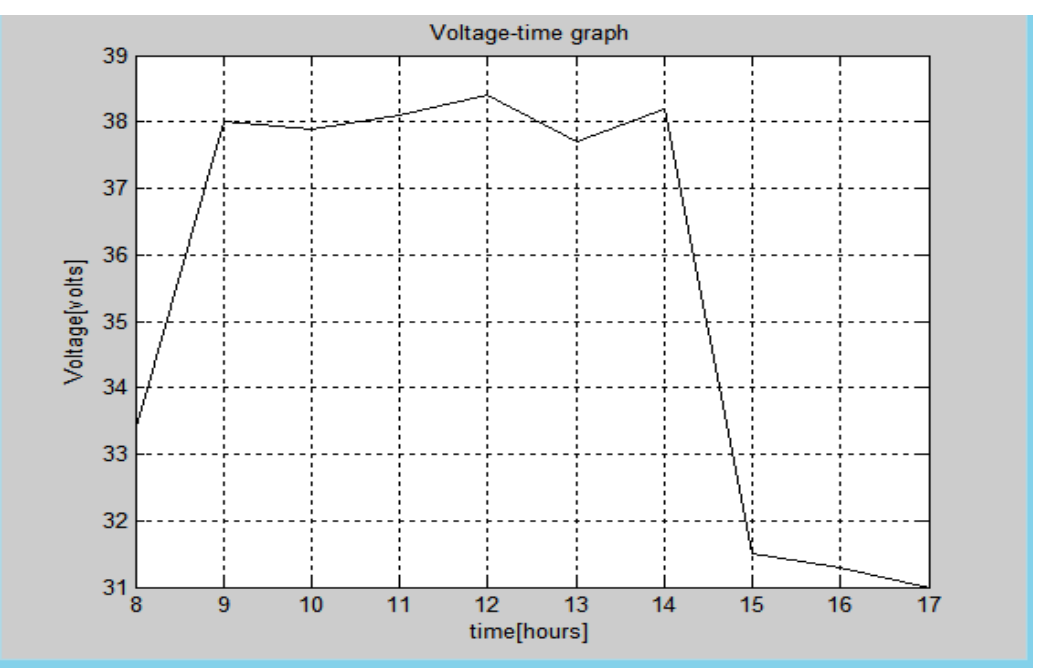




\section{Graph of Voltage against Time}

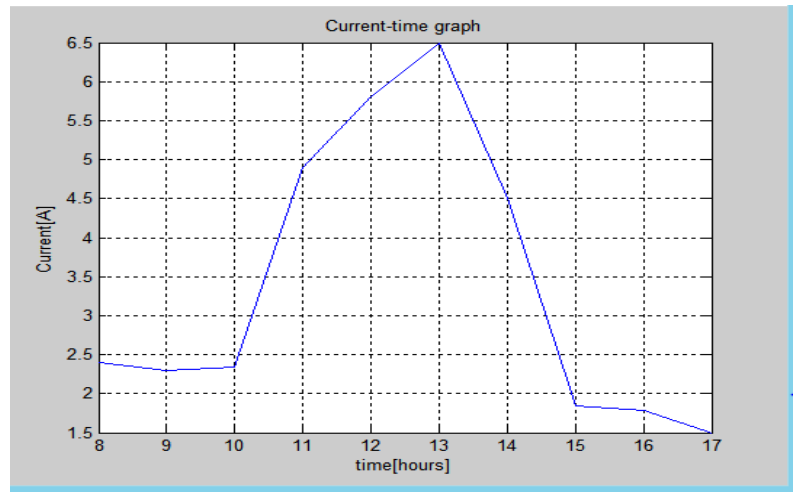

\section{Graph of Current against Time}
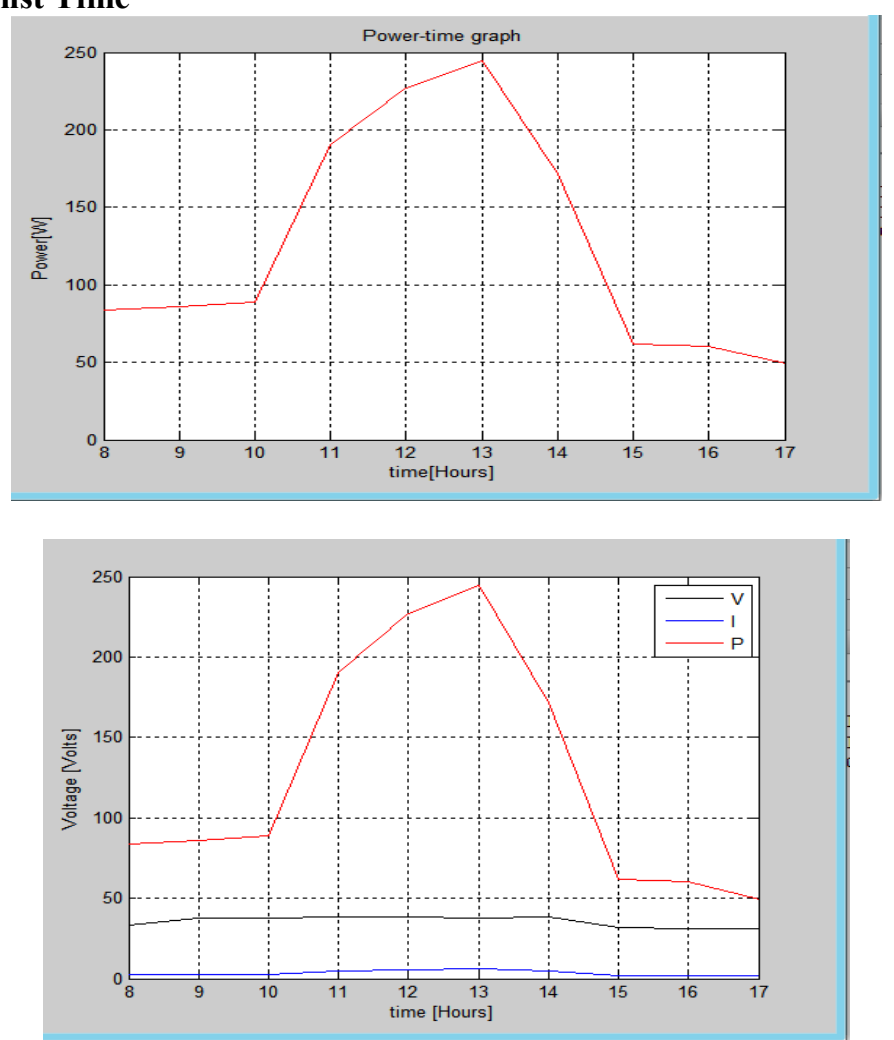

\section{Depth of discharging of battery}

It is imperative that the rate at which the battery discharge be assessed. Therefore

\section{Depth of discharging of battery $=\frac{\text { Daily total load (Ah) }}{\text { Capacity of battery }(\mathrm{Ah})}$......................3}

It was noticed that the load varies from day to day, time to time, therefore the depth of discharging assessment procedure was calculated based on full load, half load and one third load as seen.

Daily total load at full load $=7320 \mathrm{Wh}$

Daily total load at half load $=\frac{7320}{2}=3660 \mathrm{Wh}$

Daily total load at one-third of load $=\frac{7320}{3}=2440 \mathrm{Wh}$

To convert from Wh to Ah:

$\mathrm{Ah}=\frac{W h}{V}$

Where $\mathrm{Ah}=$ Ampere hour

$\mathrm{Wh}=$ Watt hour

$\mathrm{V}=$ Battery Voltage 
From equation 4 we have that;

For full load $=\frac{7320 \mathrm{Wh}}{24 \mathrm{~V}}=305 \mathrm{Ah}$
At half load $=\frac{3660 \mathrm{Wh}}{24 \mathrm{~V}}=152.5 \mathrm{Ah}$
At one third load $=\frac{2440 \mathrm{Wh}}{24}=101.6667 \mathrm{Ah}$

From equation 3 we have that;

Depth of discharge at full load $=\frac{305 \mathrm{Ah}}{400 \mathrm{Ah}}=0.7625$

Dept of discharging at half load $=\frac{152.5 \mathrm{Ah}}{400 \mathrm{Ah}}=0.3813$

Dept of discharging at one third load $=\frac{101.6667 \mathrm{Ah}}{400 \mathrm{Ah}}=0.2542$

From the graph above, it was noticed that:

1. That the energy available from the sun source varies from time to time during the day

2. That the available energy radiant from the sun source varies from day to day during the year.

3. That the voltage, current and power due to radiance from the sun source varies from time to time, day to day and year to year.

\section{Conclusion}

A typical solar module consists of series connection of solar cells to get practically utilisable voltage. A number of such modules are connected together in series and parallel to get the requisite power. From the results and inferences from this project, it is concluded that there is a substantial power loss due to non-uniform illumination of a series string. The power generated by highly illuminated cells is wasted as a heat in the poorly illuminated cells. So, care should be taken to see that all the cells connected in series receive the same illumination under different patterns of shading. Such a care will give a better protection to the array and at the same time the total energy output will also be higher.

\section{References}

[1] J. Perlin. From Space To Earth (The Story Of Solar Electricity). Harvard University Press: London, 1999.

[2] Solar Energy Technologies and Applications, CANREN: www.canren.gc.ca/techappl/index.asp? caid=5\&pgid=121, Sept. $4^{\text {th }}, 2011$

[3] G. John. Photovoltaics: Solar Electricity and Solar Cells in Theory and Practice.Internet: http://www.solarserver.com, Oct. 21 , 2011

[4] K. Gil, (2004) "How do Photovoltaic Work?” Science News.1 (1), p 4.

[5] L. David. "Handbook of Batteries". McGraw-Hill: New York, 2002.

[6] "Wiring solar panels". Internet: www.solar-facts.com/wiring solar panels, Dec. 5, 2011

[7] "How charge controllers work". Internet: www.altestore.com/charge-controllers/c432

[8] “Solarregulators".Internet:www.enegrymatters.com/au/renewableenergy/solarregulator/charge-controller, Aug. $17^{\text {th }}, 2011$.

[9] "Inverters". Internet: www.en/wikipedia.org/wiki/inverter_(electrical), Jun.1, 2011.

[10] J. Mervin et al. Contemporary Energy Issues Grid-Connected Solar Electronics.Department of Electrical Engineering and Computer Sciences.EE-290N-3; University of California, 2002.

[11] "Deep cycle batteries". Internet: www.en/wikipedia.org/wiki/deepcyclebatteries, Nov. 4, 2011

[12] “Operation of Circuit Breakers". Internet: www.en/wikipedia.org/wiki/circuit_breakers, Nov. 7, 2011

[13] V. Quaschning and R. Hanitsch,"Numerical simulation of current-voltage characteristics of photovoltaic systems with shaded solar cells," Solar Energy, vol. 56, no. 6, pp. 513-520, 1996.

[14] J. H. R. Enslin, M. S. Wolf, D. B. Snyman, and W. Swiegers, "Integrated photovoltaic maximum power point tracking converter," IEEE Transactions on Industrial Electronics, vol. 44, no. 6, pp. 769-773, 1997.

[15] M. Klenk, S. Keller, L. Weber et al., "Investigation of the hotspot behaviour and formation in crystalline silicon Power cells, PV in Europe, From PV technology to energy solutions," in Proceedings of the International Conference, pp. 272-275, 2002.

[16] A. Woyte, J. Nijs, and R. Belmans, "Partial shadowing of photovoltaic arrays with different system configurations: literature review and field test results," Solar Energy, vol. 74, no. 3, pp. 217-233, 2003.

[17] M. C. Alonso-Garc'́a, J. M. Ruiz, and W. Herrmann, "Computer simulation of shading effects in photovoltaic arrays," Renewable Energy, vol. 31, no. 12, pp. 1986-1993, 006.

[18] M. C. Alonso-Garc'1a, J.M. Ruiz, and F. Chenlo, "Experimental study of mismatch and shading effects in the I-V characteristic of a photovoltaic module," Solar Energy Materials and Solar Cells, vol. 90, no. 3, pp. 329-340, 2006.

[19] N. Femia, G. Lisi, G. Petrone, G. Spagnuolo, and M. Vitelli, “Distributed maximum power point tracking of photovoltaic arrays: novel approach and system analysis," IEEE Transactions on Industrial Electronics, vol. 55, no. 7, pp. 2610-2621, 2008. 